\title{
GREVE DE 1996 EM PRESIDENTE PRUDENTE - SP: UM OLHAR SOBRE CONSCIÊNCIA DE CLASSE, SINDICALISMO DOCENTE E MULHERES EM LUTA
}

\author{
Laiane Vieira dos Santos ${ }^{1}$, Thiago Granja Belieiro ${ }^{2}$ \\ ${ }^{1}$ Graduanda em História na Universidade do Oeste Paulista - UNOESTE, Presidente Prudente, SP. E-mail: \\ laianevs5@hotmail.com \\ ${ }^{2}$ Doutor em Historia pela Universidade Estadual Paulista - UNESP. Docente da Universidade do Oeste Paulista - \\ UNOESTE, Presidente Prudente, SP.
}

\section{RESUMO}

O presente artigo está inserido nas propostas de estudos de História regional e local. Concentra-se aqui a greve de 1996 em Presidente Prudente, cidade interiorana do estado de São Paulo, com olhares voltados a manifestação espontânea de consciência da experiência coletiva que é a greve, determinada por experiências individuais e em momentos coletivas, de classe. A greve inicia-se em 06 de maio e termina no dia 29 do mesmo mês de 1996, resultando em 23 dias de experiência grevista, por servidores públicos municipais. A teorização é por meio das ideias do historiador Edward Palmer Thompson, inserido na escola britânica do marxismo, conhecida como marxismo cultural. Conceitos como, classe, consciência de classe e luta de classes, são pensados a partir das obras do autor. A busca da compreensão (experiência e discurso) dos sujeitos da ação, nos permitiu mergulharmos na própria ação estudada, análise de fontes são desenvolvidas para melhor interpretação do estudo.

Palavras-chave: Experiência; Classe; Consciência; Greve; Cultura.

\section{STRIKE OF 1996 IN PRESIDENTE PRUDENTE - SP: A LOOK AT CLASS CONSCIOUSNESS, TEACHING UNIONS AND WOMEN IN FIGHT}

\begin{abstract}
The present article is inserted in the proposals of studies of regional and local history. The 1996 strike in Presidente Prudente city, an inner city of the state of São Paulo, focuses on the spontaneous manifestation of awareness of the collective experience that is the strike, determined by individual experiences and collective moments of class. The strike begins on May 6th and ends on June 29th, 1996, resulting in 23 days of striking experience by municipal public officers. Theorizing is through the ideas of the historian Edward Palmer Thompson, inserted in the British school of Marxism, known as cultural Marxism. Concepts such as class, class consciousness and class struggle are thought from the works of the author. The search for understanding (experience and speech) of the subjects of the action, allowed us to delve into the own action studied, analysis of sources are developed for a better interpretation of the study.
\end{abstract}

Keywords: Experience; Class; Consciousness; Strike; Culture.

\section{INTRODUÇÃO}

O presente artigo trata-se de um estudo com foco bibliográfico e teórico nas ideias do historiador britânico Edward Palmer Thompson (1924-1993) e a análise teórico-prática em uma greve local, na cidade de Presidente Prudente, interior de São Paulo no ano de 1996. Thompson é pertencente ao movimento conhecido como "escola britânica do marxismo ou história marxista inglesa", que em meados do século XX, reestruturam e ampliaram a tradicional teoria marxista, principalmente por dar atenção a um elemento fundamental nas relações de classe: a cultura. A greve chama atenção pela sua dimensão e alcance dentro da trajetória do SINTRAPP (atual Sindicato dos Trabalhadores no Serviço Público Municipal de Presidente Prudente e Região). 
Visando $o$ aprofundamento $e$ compreensão do conceito de consciência de classe e considerando também, a gama de abstrações conceituais que permeiam essa área a ser estudada, o estudo submete-se a apreensão de elementos teóricos, para consequentemente a investigação em um caso real específico, amparado na teoria desenvolvida por Thompson.

Sendo um movimento de massa, resgatase aqui, o anseio por fazer "história vista de baixo" (SHARPE, 1992, p.39), movimento impulsionado no século $X X$, uma história social mais conectada com a realidade social e histórica dos excluídos, longe dos grandes holofotes que uma minoria social sempre deteve, mas sim, uma história mais digna com a maioria, que busca o olhar da mesma, que os reconhece, que tenta compreender, que possibilita dar voz, aprova a coragem da luta de suas próprias experiências e vida. O que levaram os sujeitos a entrarem em greve? $O$ que conversavam entre si? 0 que assistiam? 0 que ouviam na rádio? $O$ que as pessoas falavam na rua ou no local de trabalho? Quais eventos culturais ocorriam? 0 que incomodava eles? Como eles se organizaram? Enfim, perguntas como essas devem ser incluídas, na medida que podem ser ilustrativos da história de vida dessas pessoas, suas experiências e manifestações históricas e culturais como experiência e manifestação social.

O estudo traz ainda a perspectiva de trabalhar com História Local e Regional, ao trazer o foco de pesquisa para Presidente Prudente, podendo, com isso, significar nossos contextos, nossos locais, nossas existências, ampliando assim, a sistemática de fazer conhecimento com a própria localidade. Fazer história sob o prisma local e regional encontra-se em uma nova ótica já de se fazer história e ao unir esse caminho com aquele proposto por Thompson, podemos contribuir de forma crítica e reflexiva para acontecimentos históricos relevantes para a cidade de Presidente Prudente.

$\mathrm{Na}$ trajetória de luta do SINTRAPP, é possível observar, em vários momentos, a conexão e presença de um sindicalismo docente, atuando junto aos demais integrantes da organização sindical, em seus movimentos. $O$ que expõe, então, uma das facetas que compõem um sindicato vivo, combativo, necessário e protagonista de grandes lutas para contar.

\section{MÉTODOS}

E. P. Thompson (1924-1993) define o conceito de classe como uma entidade, logo, impossível talvez de ser compreendida como algo extremamente racional, visto que, a classe é um misto espontâneo de aferimentos, é presente como a existência da vida. Sua análise se desprende do tradicional marxismo, pelo fato de não considerar a classe como algo apenas metódico e racionalizado, sendo impossível pensar para Thompson a mesma como um número tal de pessoas, localizadas em específico lugar com tal hábito. A questão mais importante aqui a ser compreendida, é a dimensão do conceito "classe" na ótica thompsiniana, desprendendo-se do sentido tradicional (do marxismo) de algo determinado e racional, para um fenômeno processual e espontâneo.

\begin{tabular}{|c|}
\hline $\begin{array}{l}\text { Por classe, entendo } \\
\text { fenômeno histórico, } \\
\text { unifica uma série } \\
\text { acontecimentos díspa } \\
\text { aparentemente } \\
\text { desconectados, tanto } \\
\text { matéria-prima } \\
\text { experiência como } \\
\text { consciência. Ressalto } \\
\text { é um fenômeno histó } \\
\text { Não vejo a classe c } \\
\text { uma "estrutura", } \\
\text { mesmo como } \\
\text { "categoria", mas } \\
\text { algo que oc } \\
\text { efetivamente (e } \\
\text { ocorrência pode } \\
\text { demonstrada) nas rela } \\
\text { humanas [...] a noçãa } \\
\text { classe traz consigo a n } \\
\text { de relação histórica. C } \\
\text { qualquer outra relaçã } \\
\text { algo fluido que esca } \\
\text { análise ao tental } \\
\text { imobilizá-la num } \\
\text { momento e dissecar } \\
\text { estrutura [...] a rel } \\
\text { precisa estar ser } \\
\text { encarnada em pesso } \\
\text { contextos } \\
\text { (THOMPSON, 2004, } \\
\text { 10). }\end{array}$ \\
\hline
\end{tabular}

A consciência de classe então, caminhando nesse sentido, seria a representação espontânea da classe, admitindo pelo entendimento dos conceitos que, parafraseando Thompson (2004) "a classe vive como experiência determinada, ocorre efetivamente nas relações 
humanas, e assim a consciência como manifestação espontânea da experiência...". Logo, a consciência é uma ação decorrente e natural do processo.

\begin{abstract}
A consciência de classe é a forma como essas experiências são tratadas em termos culturais: encarnadas em tradições, sistemas de valores, ideias e formas institucionais. Se a experiência aparece como determinada, o mesmo não ocorre com a consciência de classe. Podemos ver uma lógica nas reações de grupos profissionais semelhantes que vivem experiências parecidas, mas não podemos predicar nenhuma lei. A consciência de classe surge da mesma forma em tempos e lugares diferentes, mas nunca exatamente da mesma forma. (THOMPSON, 2004, p.10).
\end{abstract}

Reconhecendo a premissa inicial do Manifesto do partido comunista ${ }^{1}$ : "a história de todas as sociedades que existiram até hoje tem sido a história da luta de classes" (MARX; ENGELS, 1988, p. 75), e interpretando por meio dos estudos de Thompson o fazer-se da classe e consciência, buscamos em um caso específico, esmiuçar as partículas que compõem a experiência e sua ação, em limitação de tempo e espaço. Bem como sua presença e valor sociocultural.

Evidentemente, a questão é como o indivíduo veio a ocupar esse "papel social" e como a organização social específica (com seus direitos de propriedade e estrutura de autoridade) aí chegou. Estas são questões históricas. Se detemos a história num determinado ponto, não

\footnotetext{
1 Manifesto do Partido Comunista: Uma das obras clássicas da produção marxista, publicado pela primeira vez em 1848, foi escrito por Karl Marx e Friedrich Engels. Sendo reconhecida pela grande valia na exposição de vários conceitos essenciais para a estruturação e entendimento dessa teoria.
}

há classe, mas multidão de indivíduos com um amontoado de experiências. Mas se examinarmos esses homens durante um período adequado de mudanças sociais, observaremos padrões em suas relações, suas ideias e instituições. A classe é definida pelos homens enquanto vivem sua própria história e, ao final, esta é sua única definição. (THOMPSON, 2004, p. 1112).

O processo que gera a experiência e as ações, são tidos então como o objeto central do estudo, tudo está envolvido, então, estuda-se todas as inserções correlacionadas ao processo, que em certo ponto de vista, é a própria vida dos sujeitos envolvidos. $\mathrm{Na}$ perspectiva de aprofundamento dessas relações e experiências, encontramos suas manifestações, e aqui deve-se buscar as significâncias. Thompson distingue no segundo volume de $A$ formação da classe operária inglesa - a maldição de Adão (THOMPSON, 2002, p.36-37), as ideias de padrão de vida e modo de vida, o autor afirma:

Nesse ponto, uma nova
série de dificuldades
principia, já que o termo
"padrão nos leva de
informações susceptíveis
de medição estatística
(salários ou artigos de
consumo) para aquelas
satisfações algumas vezes
descritas como
"imponderáveis" pelos
estatísticos.
alimentação passamos à
moradia, da moradia à
saúde, da saúde à vida
familiar, e desse ponto ao
ócio, à disciplina no
trabalho, à educação e
lazer, à intensidade do
trabalho, e assim por
diante. Do padrão de vida,
passamos ao modo de
vida. Mas eles não
significam a mesma coisa.
O primeiro é uma medida
de quantidades; o


segundo, uma descrição

(e, às vezes, uma avaliação) de qualidades. Enquanto as evidências estatísticas são apropriadas para o primeiro caso, precisamos confiar em "dados literários" para o segundo. A principal fonte de confusão surge quando se procuram extrair conclusões para um caso a partir de dados apropriados apenas para o outro [...] é perfeitamente possível que médias estatísticas e experiências humanas conduzam a direções opostas. (THOMPSON, 2002a, p.3637).

Dando seguimento a construção da linha de análise nas várias formas de manifestações, no terceiro volume de $A$ formação da classe operária inglesa- a força dos trabalhadores (THOMPSON, 2002, p.411-412), o autor disserta sobre duas perspectivas da consciência de classe dentro do seu específico estudo que eram os trabalhadores da Inglaterra, em período temporal também limitado. Todavia, os apontamentos que o mesmo elenca nesse seguimento, também nos serve de fomento para a reflexão, quanto o fazerse a ser analisado no estudo. Ele disserta:

A nova consciência de classe dos trabalhadores pode ser vista de dois aspectos. De um lado, havia uma consciência da identidade de interesses entre trabalhadores das mais diversas profissões e níveis de realização, encarnada em muitas formas institucionais e expressa, numa escala sem precedentes, no sindicalismo geral de 1830-34 [...] Por outro lado, havia uma consciência de identidade dos interesses da classe operária, ou "classes produtivas", enquanto contrários aos de outras classes; dentro dela, vinha amadurecendo reivindicação de um sistema alternativo. Mas a definição final dessa consciência de classe era consequência, em grande parte, da reação da classe média à força operária. (THOMPSON, 2002b, p.411-412).

Elencados conceitos e apontamentos sobre, partiremos dessas ideias para o estudo focalizado da greve de 1996 em Presidente Prudente- SP. Em um primeiro momento já na análise (com os conceitos já apreendidos), contextualizaremos o espaço temporal e local do acontecido, em seguida apontamentos sobre o sindicalismo nacional e o SINTRAPP, para o entendimento da greve.

A discussão será embasada pela concepção thompsiniana, leitura sobre sindicalismo nacional e uma monografia local na área de humanas sobre o próprio sindicato, a investigação em periódicos relacionados e a análise interpretativa das fontes coletadas. Lemos para a própria análise, o antropólogo estadunidense Clifford Geertz (1926 - 2006), com sua prática de uma Antropologia Interpretativa, para ele a Cultura é um emaranhado de símbolos, carregados de significados, ele disserta sobre:

No entanto, esse é um objetivo ao qual o conceito de cultura semiótico se adapta especialmente bem. Como sistemas entrelaçados de signos interpretáveis (o que eu chamaria símbolos, ignorando a sutilizações provinciais), a cultura não é um poder, algo ao qual podem ser atribuídos casualmente os acontecimentos sociais, os comportamentos, as instituições ou os processos; ela é um contexto, algo dentro do qual eles podem ser descritos de forma inteligível- isto é, descritos com densidade (2008, p.10).

Em seu livro A interpretação das Culturas (GEERTZ, 2008), publicado pela primeira vez em 1973, ele argumenta sobre a conceituação da "Descrição densa", a interpretação um tanto que microscopia e profunda por meio de um ser 
particular e também a relação da interpretação cultural com a teoria. Como cita na obra, Geertz (2008, p.17): "Com efeito, quanto mais longe vai o desenvolvimento teórico, mais profunda se torna a tensão". Sendo assim, todas apostas são para a tentativa de resgatar elementos subjetivos e objetivos nas fontes usadas e interpretá-los, ao ponto do fazer-se da experiência, vivência coletiva, e sua manifestação discursiva.

\section{RESULTADOS E DISCUSSÃO}

Pensar os docentes, enquanto categoria, nunca foi uma tarefa fácil, visto que particularidades estão presentes. A docência na educação básica (dividida atualmente em ensino fundamental e médio) e a educação superior, por exemplo, demonstram não apenas diferenciações procedimentais, mas sim, trajetórias, realidades e representações discursivas distintas e próprias, não excluindo a ideia de união, mas sim, dificultando a formação de uma união plena entre as categorias de professores. Nesse sentido, levantar sobre a trajetória do sindicalismo docente, inicialmente pede a reflexão sobre a categoria de experiência docente.

A existência das associações antecedeu os sindicatos, a própria transformação está relacionada a mudanças tanto conjunturais quanto estruturais que a influenciaram. Como disserta Gouveia e Ferraz (2013, p.117), após um período de repressão, oriundo da ditadura militar brasileira, no período pós ditatura, com a reabertura democrática, temos a Constituição de 1888, que determina papel fundamental dentro do processo de ação e representação dessas entidades. No artigo 37 da Constituição, inciso VI, será garantido à livre associação sindical (ao servidor público civil), e, no próximo inciso do mesmo artigo, o direito de greve ao servidor. Com a legalização constitucional então, temos a passagem de diversas associações de professores e educação, em sindicatos de trabalhadores.

O final dos anos de 1970, a década de 1980 e a primeira metade dos anos de 1990 presenciaram transformações

qualitativas na prática de mobilização coletiva e de representação de interesses dos professores brasileiros, assim como a consolidação de um novo marco institucional para a política educacional. No final dos anos de 1970, em função das reformas educacionais do regime militar, o número de professores na rede pública havia crescido exponencialmente, a perspectiva de profissionalização e valorização do magistério havia sido sinalizada pelos Estatutos Estaduais e Municipais do Magistério, mas as condições de trabalho permaneciam precárias e o rendimento dos professores sofria um processo de depreciação constante, principalmente após a crise do petróleo. Esse cenário de arrocho salarial e a perspectiva de construção de uma identidade profissional tornaram-se combustíveis para um ciclo de mobilizações coletivas e de greves, com caráter tipicamente trabalhista que os professores ainda não tinham experimentado em toda a história brasileira (NOGUEIRA, 2005. Et al. apud GOUVEIA; FERRAZ, 2013, p. 116).

Compreender a passagem das associações para sindicatos, é um ponto fundamental para pensar o entendimento no plano das mentalidades do sindicalismo docente, sua representatividade e seu discurso. Visto que, o processo adjunto a passagem, está em superar a ideia de que um professor é uma figura quase que "sagrada" de uma sociedade e que possui uma missão, a de educar, assim abrindo mão de melhores condições de trabalho, de salários dignos e respeito. Passando então, a reconhecerse também enquanto trabalhador assalariado, que luta por seus direitos trabalhistas, melhores condições e propostas, ou seja, encontramos aqui, não apenas um professor por "vocação ou dom" e sim, também, um professor consciente, com sua formação e visto agora, como força política. Significa dizer que há enfrentamento (por meio deles) de inúmeros problemas de 
ambas vertentes, só que a partir desse momento, em sua preponderância, esclarecido a força sindical política dos docentes. Disserta em específico sobre a APEOESP (Sindicato dos Professores do Ensino Oficial do Estado de São Paulo), o historiador Ricardo Pires de Paula:

$\mathrm{Na}$ medida em que se legitimavam frente aos docentes dos diferentes níveis de ensino e perante - Estado, suas práticas eram renovadas, assim como eram reformuladas as suas regras de funcionamento, constituindo novos "habitus". Estes refletiam e refratavam não apenas os embates vivenciados no campo educacional, mas as transformações sociais, políticas, econômicas e culturais ocorridas no Brasil e no Estado de São Paulo ao longo de sua trajetória (PAULA, 2011a, p. 287).

Em específico na cidade de Presidente Prudente, interior de São Paulo, há no final do ano de 1988 a formação do SINTRAPP (atualmente, Sindicato dos Trabalhadores no Serviço Público Municipal de Presidente Prudente e Região). Quando na data de sua fundação, em 14 de dezembro de 1988 (DE ANDRADE, 2014, p.32), o sindicato surge de uma Associação de Servidores Públicos locais, e conforme o passar do tempo, reestabelece a questão de admitir uma postura mais regionalizada, assumindo então, desde meados de 2003, um sindicato local e regional, específico para trabalhadores do serviço público. a APEOESP, mas os votos foram favoráveis à essa participação, já que os professores eram uma força representativa dentro da associação (ANDRADE, 2014, p. 32).

O SINTRAPP destaca-se, por admitir uma postura de um sindicato combativo, houve filiação com a CUT (Central Única dos Trabalhadores), (DE ANDRADE, 2014, p.34). E também pela conectividade entre gênero e sindicalismo, visto que, a presença feminina é atuante por toda a trajetória do sindicato.

O SINTRAPP mostrava-se atípico em relação à presença feminina em sua diretoria, era um sindicato que nascia com o gênero feminino incutido em sua liderança (ANDRADE, 2014, p. 34).

A participação feminina prende-nos a atenção, quando vista pela ótica do enfrentamento aos preconceitos de uma sociedade machista e patriarcal, ainda em meados de 1990. A presença da mulher, enquanto força sindical, nos expõe uma face de empoderamento feminino e quebra total de tabus da sociedade, potencializando a luta e provando da experiência de emancipação feminina, seja qual pela própria existência até pela força política.

Da chapa vencedora quase $70 \%$ dos membros que a compunham eram mulheres, algo raro se comparado aos sindicatos da época. Vale lembrar que a mulher ainda se via excluída do campo político e sindical. No ano de 1993 a CUT em um de seus congressos aprovou a cota mínima de gênero de $30 \%$ aos sindicatos filiados à Central. A cota visava desenvolver a participação feminina dentro das lutas sindicais. E no SINTRAPP o gênero masculino é que se viu com número mínimo de membros. A presidência do Sindicato passou às mãos de Genilda 
Sueli Bernardes. O ano de 1995, que marcou a tomada de posse da nova diretoria foi um ano de constantes atritos entre 0 sindicato e a prefeitura. Era um sindicato em sua maioria feminino e isso escancarou preconceito/machismo presente na sociedade [...] 0 discurso machista predominava junto à descrença da capacidade feminina nos embates políticos. A visão de que a mulher não seria capaz de liderar uma greve evidenciava o pensamento patriarcal, onde o campo político e a liderança eram atribuídos como "coisas de homem". Quando as lutas/greves davam resultado novamente 0 discurso da incapacidade e o preconceito mostravamse presentes. Isso é notado quando a sexualidade da mulher líder é colocada em xeque por ter coordenado um movimento grevista (ANDRADE, 2014, p.4142).

O ano de 1996, já começa de forma intensa na cidade de Presidente Prudente, pois, é um ano eleitoral. Com a nova direção sob o comando do sindicato e a percepção sobre as possíveis dificuldades de negociação com a prefeitura municipal, o sindicato se organiza para uma grande greve que viria acontecer. Continuando seguindo De Andrade (2014, p.45), a pauta de reivindicações pedia o aumento de $33 \%$ no salário dos servidores, na educação pedia-se a redução para seis horas diárias das auxiliares de desenvolvimento infantil (ADIs) e planos de carreira para a saúde e educação. No dia do trabalhador, houve a organização de um ato afim de expor as reivindicações e tentar a negociação, que pelo prefeito, inicialmente é descartada.

A greve foi marcada para começar no dia 06 de maio, caso não houvesse uma negociação entre sindicato e prefeitura.

Segundo dados do sindicato mais de $60 \%$ dos servidores aderiram ao movimento grevista em seu primeiro dia [...] $\mathrm{O}$ sindicato buscou a adesão de mais servidores ao movimento grevista e foi bem sucedido [...] Com a paralização de $70 \%$ do parque de obras, no dia 10 de maio havia 1.800 servidores participando do movimento grevista (ANDRADE, 2014, pg. 4546).

Conforme descreve De Andrade (2014, p.46), com a greve em andamento, no dia 13 de maio de 1996, há enfrentamento da presidente do sindicato e do prefeito local, no paço municipal onde também haviam grevistas reunidos. Houve no dia 14 do mesmo ano, uma audiência com intervenção de uma vereadora, que saiu sem negociações. Houve também por parte do sindicato, a tentativa de acordo pela subdelegacia do trabalho, que da mesma forma, não possui conciliação. No dia 17 de maio, acontece um ato bastante simbólico e radical, estavam pais e alunos junto aos grevistas.

A greve seguiu, muitos serviços básicos estavam paralisados e isso gerou uma indignação pública, que necessitava dos serviços prestados pelos servidores e passaram a pedir à prefeitura que negociasse pelo fim da greve [...] No dia 24 de maio pais de alunos do ensino municipal foram até a prefeitura pedir para que $o$ prefeito abrisse negociação com os servidores. A greve já completava 18 dias [...] Nos dias 28 e 29 do mês de maio sindicato e prefeito negociaram, e a greve chegou ao fim após 23 dias. Os grevistas tiveram 14 dias de greve bonificados e os outros sujeitos à compensação, incorporação do abono de $\mathrm{R} \$ 50,00$ ao salário (esse 
valor representava para a maioria dos servidores da época um aumento de 25\%), os processos administrativos contra os funcionários em estágio probatório foram retirados e a garantia de que a cesta básica seria mantida aos servidores (ANDRADE, 2014, pg. 48-49).

A greve em específico nos demonstra um importante momento de experiência sindical e luta, na localidade e temporalidade específica. Um palco de experiências e simbologias. Cabenos aqui, tentar reunir fragmentos de sua memória e destrincha-los. As imagens selecionadas abaixo, expõem várias vertentes sobre essa experiência e nos fomenta a interpretação das mesmas, no sentido de percebermos nuances que indiquem a presença, nessa greve, de elementos indicativos de consciência de classe, tal como proposto por Thompson.

Na figura 1, foto da mobilização docente da greve de 1996, temos uma criança segurando um cartaz, significando o envolvimento e os sujeitos (o responsável pela criança). Houve a atitude de estar presente no ato, e houve a atitude de levar uma criança junto ao mesmo. Pensamos, portanto, que essa criança deveria ser aluno ou filho de professor ou professora mobilizada, provavelmente, de creches do ensino infantil que estavam paralisadas. De qualquer modo, a presença da infância na figura de uma criança, em um ato grevista organizado, traz indicações referentes à presença do envolvimento familiar no embate grevista.

Figura 1. Um dos atos organizados durante a greve de maio

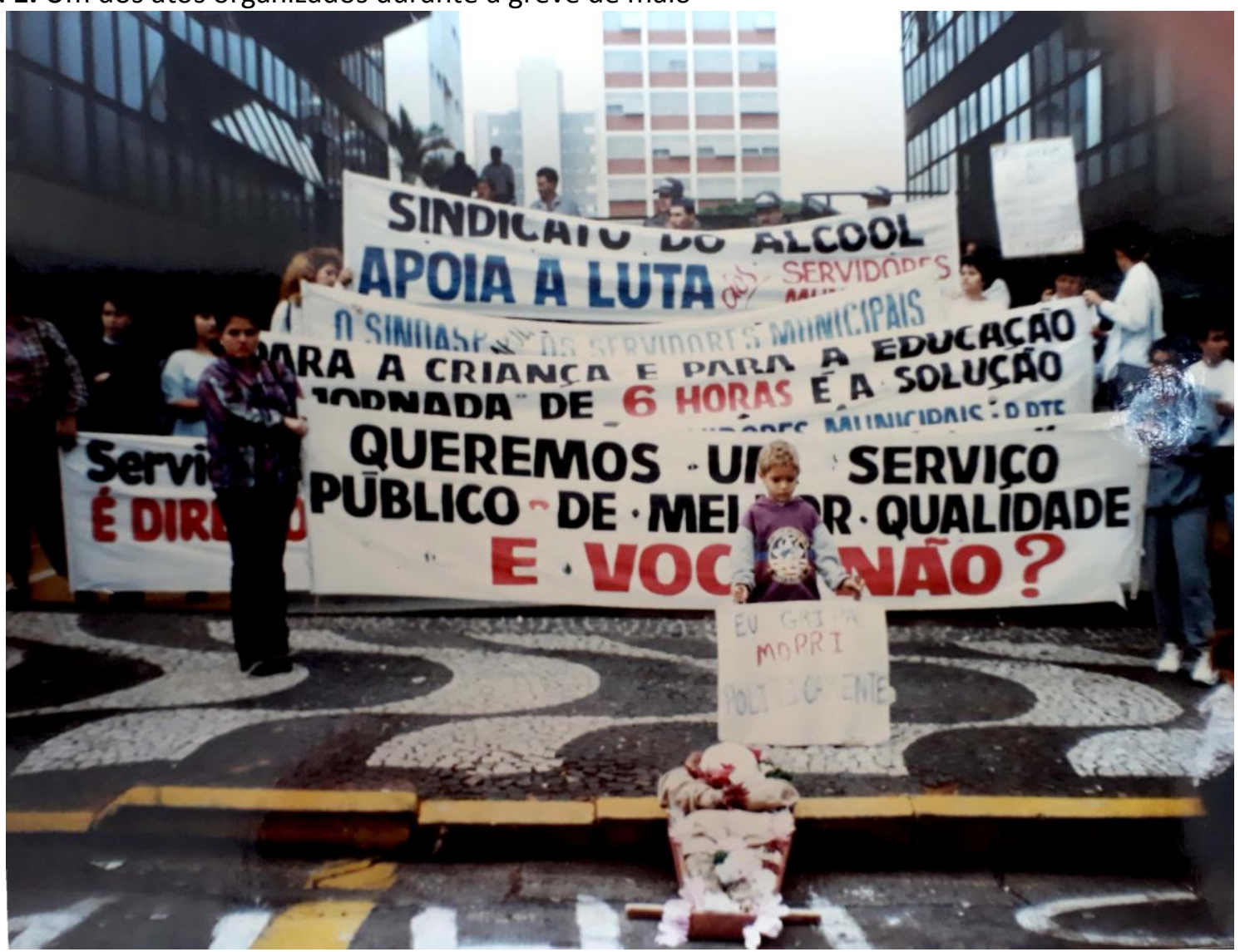

Fonte: Acervo do SINTRAPP, 1996.

Em atenção voltada a questão da linguagem encontrada nas faixas, também nos apresenta uma gama de aferimentos. "Queremos um serviço público de melhor qualidade. E você não?", nos deixa evidente que, os servidores grevistas traziam com seu discurso a ideia de que, mesmo outras pessoas que não estavam participando da greve e não estavam envolvidas àquela experiência, estavam sim conectadas no sentido de ser afetadas, porque o serviço público 
é para todos. A ideia de alcance e funcionalismo no sentido discursivo das faixas presentes, demonstram a atitude de chamar a atenção, para a premissa de que o serviço alcança "você", por isso a indagação final da faixa específica. Ela traz ao receptor e leitor, a ideia de que, "você" também está envolvido nesse processo.

Existem duas faixas que são de outros sindicatos (Sindicato do álcool e SINDASP) declarando apoio à greve. Remonta a ideia de trabalhadores em geral, unidos na luta. É interessante refletir sobre, um sindicato de liderança feminina, com ações combativas e alcance para outras estruturas do trabalho, em plena década de 90. A busca árdua da superação do machismo e patriarcalismo pelo empoderamento feminino sindical, em experiência e ascensão.

Em outra faixa, é possível enxergar "para a criança e para a educação, jornada de 6 horas é a solução", em letras maiúsculas, que era uma das reivindicações no setor da educação infantil. Outro ponto importante a ser observado é que, ao escreverem "para a criança", abrem o sujeito tanto a criança, para também os envolvidos com essa própria, o protesto então, passa não ser apenas das auxiliares do desenvolvimento infantil, e sim, afeta e envolve a questão familiar e todos os envolvidos na educação, tanto o trabalhador quanto ao usufruidor da mesma. Mais uma vez o discurso amplo e envolvente dos grevistas

É válido, reconhecer na forma como a linguagem é colocada nas faixas de protesto, um indicativo de consciência de classe, porque, as faixas não limitam o movimento a apenas aqueles que estão concentrados na ação grevista diretamente, pelo contrário, ela determina quem são os sujeitos grevistas e o que querem, e em seguida, ampliam o contato com o movimento em si e com todas as formas em que ele veio a atingir, seja de maneira direta ou indiretamente, todos os cidadãos. Uma construção que permitiu ser vista e que indagava, inclusive, a todos aqueles que por ali passavam ou viam. Nos demonstra, uma nuance de expansão ao movimento e tentativa de conscientizar a todos, mesmo aqueles que não, diretamente, estavam participando da ação.

Observamos também, em primeiro plano da fotografia, o que seria a representação de um caixão, neste ato, existe por parte dos grevistas um enterro simbólico político, uma forma simbólica de demonstrar o repúdio deles perante o mandato do dirigente local e a relação entre o mesmo e a greve.

Figura 2. Grevistas no ato organizado durante a greve

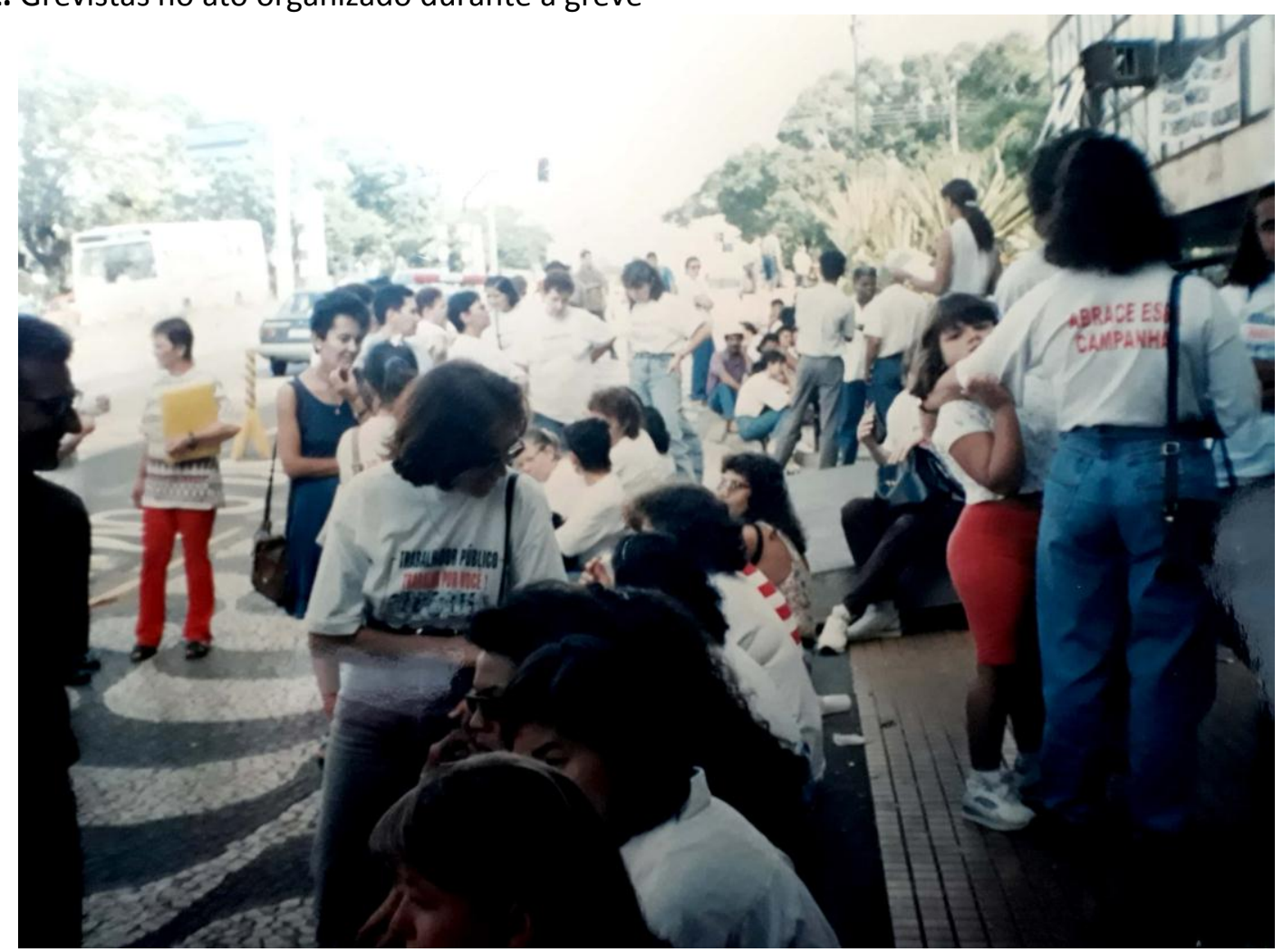

Fonte: Acervo do SINTRAPP, 1996. 
Analisemos na figura 2, a quantidade de mulheres envolvidas no movimento e filiadas muitas vezes ao sindicato. Mais uma vez observase uma criança junto a uma integrante do ato. Um protagonista em várias fotos vistas, é a vestimenta. A camiseta dessa mulher, que está em pé e frente ao plano em que a foto foi tirada, diz "trabalhador público trabalha por você", nos oferece duas importantes visões, a primeira, confirmamos mais uma vez, a questão do discurso que envolve todos, e não apenas os grevistas. É uma greve de "específicos" para muitos (essa é a ideia), porque a função do serviço público é e deveria ser um trabalho destinado para todos. Na mulher que está de costas a foto, observamos "abrace essa campanha" (tudo indica que faz parte da mesma camiseta: "trabalhador público trabalha por você, abrace essa campanha"), que também em outras fotografias, são vistas em muitas pessoas, assim ocorre com a camiseta do setor da saúde (usado, ao que deduzimos, sempre pelas pessoas do setor da saúde). A segunda exposição, é a questão de que nas fotos observadas da greve, sempre existia uma parcela dos integrantes com mesmas camisetas e isso demonstra a ideia de organização por parte de vestimentas, que significa tanto a questão da experiência coletiva de classe, como a simbologia da própria vestimenta na experiência grevista, as camisetas falavam por si só.

Figura 3. Boneco simbólico com mensagem

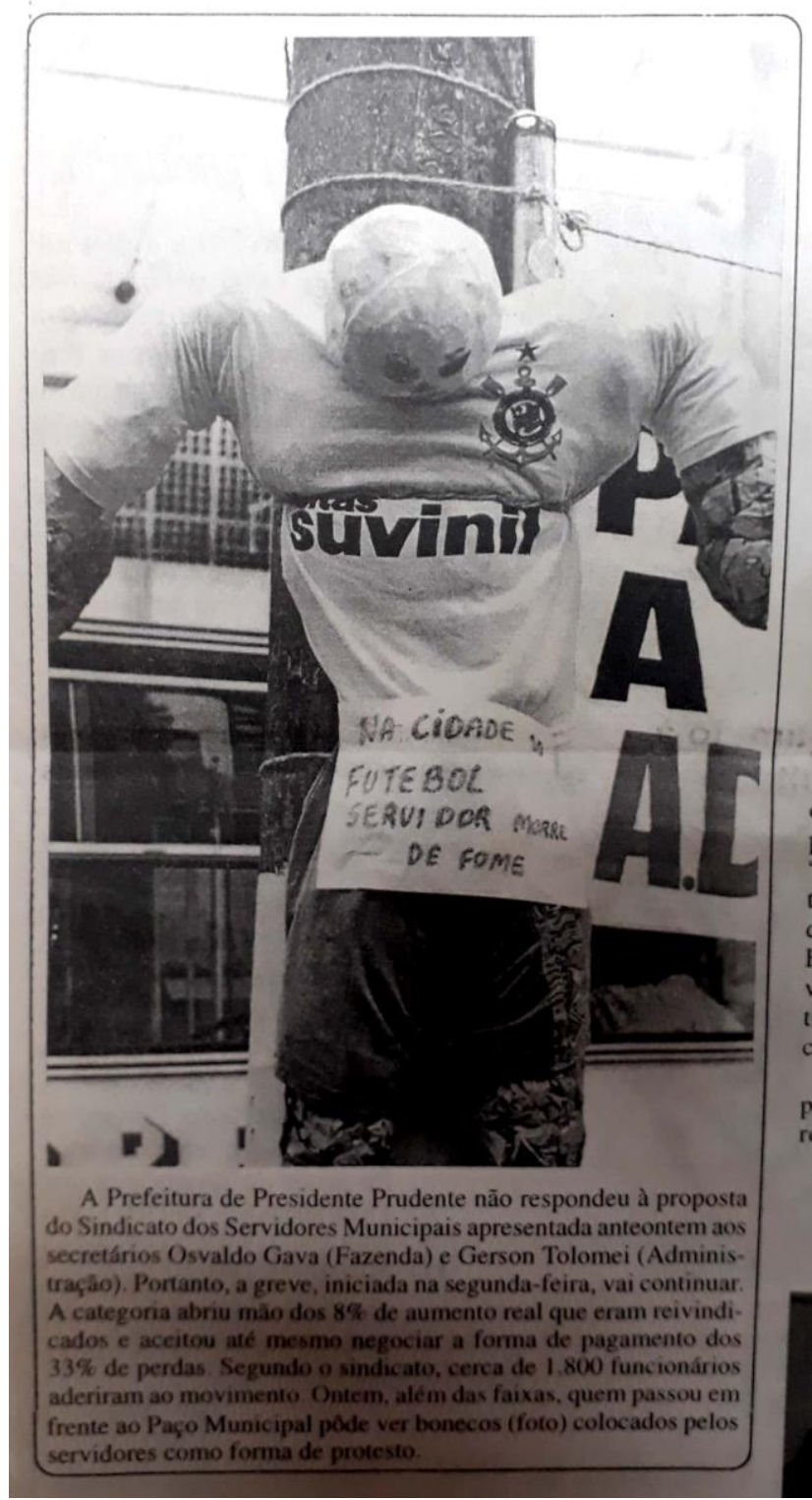

Fonte: Jornal, O Imparcial, Mai, 1996. 
Interessa-nos aqui, o destaque para algumas expressões vistas amplamente durante toda a análise de fotografias no acervo do sindicato. Escrito de outra cor, de forma a destacar mais, encontramos a expressão "salários de fome" (descritos em uma faixa de apoio/protesto encontrada em uma fotografia de maio de 1996 no acervo), observado em uma outra faixa de protesto: "servidores em luto, contra a morte do serviço público" (Jornal, O Imparcial, Mai. 1996), e a exposta na imagem, um boneco amarrado ao poste, deixado em frente ao Paço Municipal pelos grevistas, de acordo com o jornal O Imparcial na edição de 11 de maio de 1996. Além da expressão do boneco, com a cabeça voltada para baixo, a mensagem carregada nos diz "na cidade do futebol, servidor morre de fome", isso explica, a camiseta de um time popular entre os brasileiros ser colocada no boneco. São expressões usadas, que estão carregadas de significativo protesto, com cargas fortes e impactantes, mesmo que para alguém que de relance, passaria e viria.
O boneco nos chama a atenção, pois, é coberto de metáforas e simbolismos, por exemplo, a colocação de uma camiseta de um time de futebol brasileiro conhecido, nos deixa dois leques de possiblidades, o primeiro, usar do futebol como uma crítica, um esporte tão difundido e prestigiado no Brasil, e ironicamente, um boneco de protesto que representaria, naquela ocasião, um servidor público, que no país do esplendor do futebol, morre de fome, naquela cidade. Em segundo, a questão da camiseta de um time popular, permitindo a questão do reconhecimento, de ambos cidadãos para com o seu time, prendendo a atenção, para a mensagem que o boneco carregava. É quase uma relação de extremos, de um lado, o futebol enquanto esporte adorado por muitos com seu vigor/investimento e de outro, a vida de um servidor público e a fome, enquanto indicativo de necessidade básica. A cabeça apontada para baixo (do boneco), nos passa a impressão de estar farto, cansado, descrente.

Figura 4. Mensagem de agradecimento do SINTRAPP a população

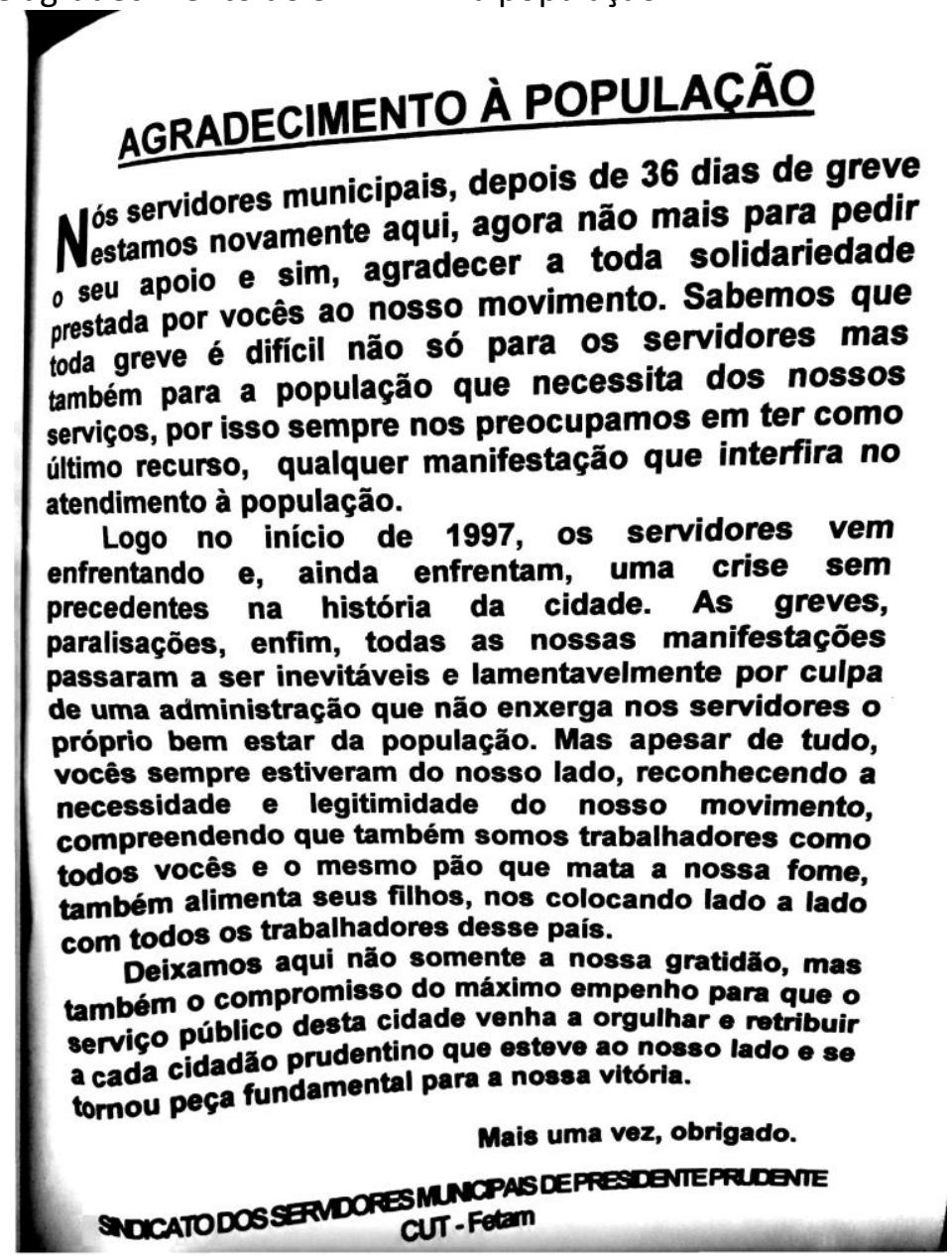

Fonte: Acervo do SINTRAPP, 1997. 
O panfleto foi escolhido, para uma análise sobre indicativos de matizes de consciência na postura do sindicato. Haja vista que, ao que se observa, o ano de divulgação desse folheto, vem a ser em 1997, ou seja, posterior a greve investigada neste estudo.

Destacamos inicialmente, o clima de cumplicidade que é observado entre o emissor (o sindicato) e o receptor dessa mensagem, que ao que tudo indica, deveria ser qualquer cidadão. Inicia-se a mensagem, saudando o respaldo para com o sindicato "agora não mais para pedir o seu apoio e sim, agradecer a toda solidariedade prestada por vocês ao nosso movimento", em seguida, apresentam uma crítica direta "as greves, paralizações, enfim, todas as nossas manifestações passaram a ser inevitáveis e lamentavelmente por culpa de uma administração que não enxerga nos servidores o próprio bem estar da população". E finalizam, reafirmando o compromisso com o receptor e ainda mais, igualando-o e trazendo proximidade entre os mesmos, é visível na fala "compreendendo que também somos trabalhadores como todos vocês e o mesmo pão que mata a nossa fome, também alimenta seus filhos, nos colocando lado a lado com todos os trabalhadores desse país".

É possível distinguir, três momentos na mensagem, e em geral, a relação entre sindicato e sociedade. $\mathrm{O}$ agradecimento, primeiramente, expõe a importância do contato e a revalidação de apoio, entre os mesmos. A crítica, afirma dizer que ainda haverá muita ação e luta, por parte do sindicato. E no final, nos é passado uma ideia de união entre trabalhadores, de proximidade de realidades.

\section{CONSIDERAÇÕES FINAIS}

Metodologicamente falando, a teorização com o historiador Edward Palmer Thompson, nos permitiu, entender os conceitos de classe, consciência de classe e luta de classes, assim, buscando a compreensão do movimento à luz de suas ideias. Bem como, estudar o antropólogo Clifford Geertz (GEERTZ, 2008) possibilitou, no momento de contato com as fontes, a interpretação das mesmas, de forma detalhada e minuciosa, ao objetivo de compreender suas simbologias e encontrar, nas mesmas, nuances indicativas de consciência.

A experiência sindical docente, encontrada no momento estudado, trouxe à tona, trabalhadores da educação, inclusive ligados ao ensino infantil, esclarecidos de sua força política. Ou seja, professores e auxiliares não somente por vocação, apáticos a qualquer imposição, e sim, trabalhadores assalariados dispostos a lutar por direitos. Assim como, a observação de muitas mulheres no movimento (muitas oriundas do setor da educação) e, inclusive, no comando do sindicato, expondo claramente, o reconhecimento das mesmas enquanto força política, superando as mazelas do patriarcado e machismo presentes na sociedade. Esse é um ponto crucial para o entendimento do SINTRAPP, enquanto um sindicato combativo e com presença feminina por toda sua trajetória, um verdadeiro símbolo de resistência e luta.

A partir da análise das fontes, concluímos importantes aferimentos sobre o movimento, seu discurso amplo, sua forma de organização e experiência coletiva e suas próprias representações. A análise das faixas de protesto, por exemplo, permitiu enxergar sempre o uso de expressões fortes e curtas empregadas nas faixas, que de primeira vista, já prenderiam a atenção a quem passasse por lá e ainda mais, incitaria a reflexão, para a realidade em que viviam. $O$ uso do boneco carregado de metáforas, também provocaria o mesmo. E nisso tudo é importante, a percepção de que havia exposição de elementos referentes ao ato (como faixas de protesto; como boneco de crítica) construídos e entregues a visão de toda a sociedade.

A elaboração de um discurso próximo ao receptor, permite o alargamento da experiência, visto que, a todo momento, o movimento não fica reservado apenas aos diretamente envolvidos, ou seja, identificamos uma experiência efetiva de classe, e encontramos nela, meios indicativos e espontâneos de consciência de classe, a abertura para a sociedade da situação do servidor, é uma questão. A proximidade e explicação da ação é presente no discurso quase sempre, trazendo à tona, a questão de envolvimento (até familiar, como a presença de crianças em atos) e reconhecimento por meio do cidadão. É externalizado um caso de igualdade perante a situação, todos serão atingidos, não apenas os servidores, mas também o que deles usufruem.

Óbvio é, de todas pontuações citadas aqui, cada própria, carrega consigo uma infinidade de estudos e percepções, que nos ocuparia anos e anos de investigação, mergulhados nas mesmas. Por conseguinte, a este presente artigo, esclarece reuni-las, 
apresentando-as e argumentando-as, embasados na teoria e análise prática de fontes, a fim da compreensão, tanto da experiência da ação, quanto de seus sujeitos. Quanto mais íntimo, mais profundo e inquietante. A experiência do estudo, haja vista que a construção na História é sempre contínua, nos possibilitou uma maior aproximação com a experiência, a memória da mesma e os envolvidos nela, dito, sujeitos históricos.

\section{REFERÊNCIAS}

CORONEL, Márcia Cristiane Völz Klumb. Pesquisa sobre gênero e sindicalismo docente: o que dizem a respeito da participação sindical das mulheres? REUNIÃO NACIONAL DA ANPED, 37., Florianópolis. Anais...Florianópolis: ANPED, 2015.

ANDRADE, Heitor Antonio Ribeiro de. Gênero e Sindicalismo: Sindicato dos Trabalhadores de Presidente Prudente, Um Sindicato de Gênero Forte (1988 - 2002). 2014. 70f. (Monografia de especialização) - Universidade do Oeste Paulista, Presidente Prudente, 2014.

GEERTZ, Clifford. Uma Descrição Densa: Por Uma Teoria Interpretativa da cultura. In: GEERTZ, Clifford. A interpretação das culturas. Rio de Janeiro: LTC, 2008, p. 3-21.

GOUVEIA, A. B.; FERRAZ, M. A. S. Sindicalismo docente e política educacional: tensões e composições de interesses corporativos e qualidade da educação. Educar em Revista, Curitiba, n. 48, p. 111-129, 2013.

MARX, Karl. ENGELS, Friedrich. Manifesto do Partido Comunista. São Paulo: Global, 1988.

PAULA, Ricardo Pires de- Uma história da APEOESP (1945-1989), entre o sacerdócio e a contestação. Jundiaí: Paco Editorial, 2011a.

PAULA, Ricardo Pires de. O sindicalismo docente e a nova história política. SIMPÓSIO NACIONAL DE HISTÓRIA - ANPUH, 26., São Paulo. Anais... São Paulo: ANPUH, 2011b.

SHARPE, Jim. A História Vista de Baixo. In: BURKE, Peter (org.) A Escrita da História: novas perspectivas. São Paulo: UNESP, 1992.
THOMPSON, E. P.- A formação da classe operária inglesa: I- A árvore da liberdade. São Paulo: Paz e Terra, 2004.

THOMPSON, E. P. A formação da classe operária inglesa: II- A maldição de Adão. São Paulo: Paz e Terra, 2002a.

THOMPSON, E. P.- A formação da classe operária inglesa: III- A força dos trabalhadores. São Paulo: Paz e Terra, 2002b.

\section{Lista de figuras}

Figura 1, Um dos atos organizados durante a greve de maio, 1996. Disponível em: Acervo do SINTRAPP.

Figura 2, Grevistas no ato organizado durante a greve, 1996. Disponível em: Acervo do SINTRAPP.

Figura 3, Boneco simbólico com mensagem, 1996. Disponível em: Jornal, O Imparcial, Mai, 1996.

Figura 4, Mensagem de agradecimento do SINTRAPP a população, 1997. Disponível em: Acervo do SINTRAPP.

Submetido em: 11/07/2018

Correções Obrigatórias: 11/11/2018

Aceite Final em: 29/11/2018 